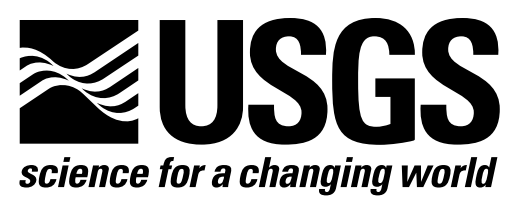

\title{
An Allocation of Undiscovered Oil and Gas Resources to Gauley River National Recreation Area and New River Gorge National River, West Virginia
}

By Christopher J. Schenk, Timothy R. Klett, Ronald R. Charpentier, Troy A. Cook, Robert A. Crovelli, Richard M. Pollastro, and Robert C. Milici

This report is preliminary and has not been reviewed for conformity with U.S. Geological Survey editorial standards or with the North American Stratigraphic Code.

Any use of trade, firm, or product names is for descriptive purposes only and does not imply endorsement by the U.S. Government.

Open-File Report 03-396

U.S. Department of the Interior

U.S. Geological Survey 


\section{Contents}

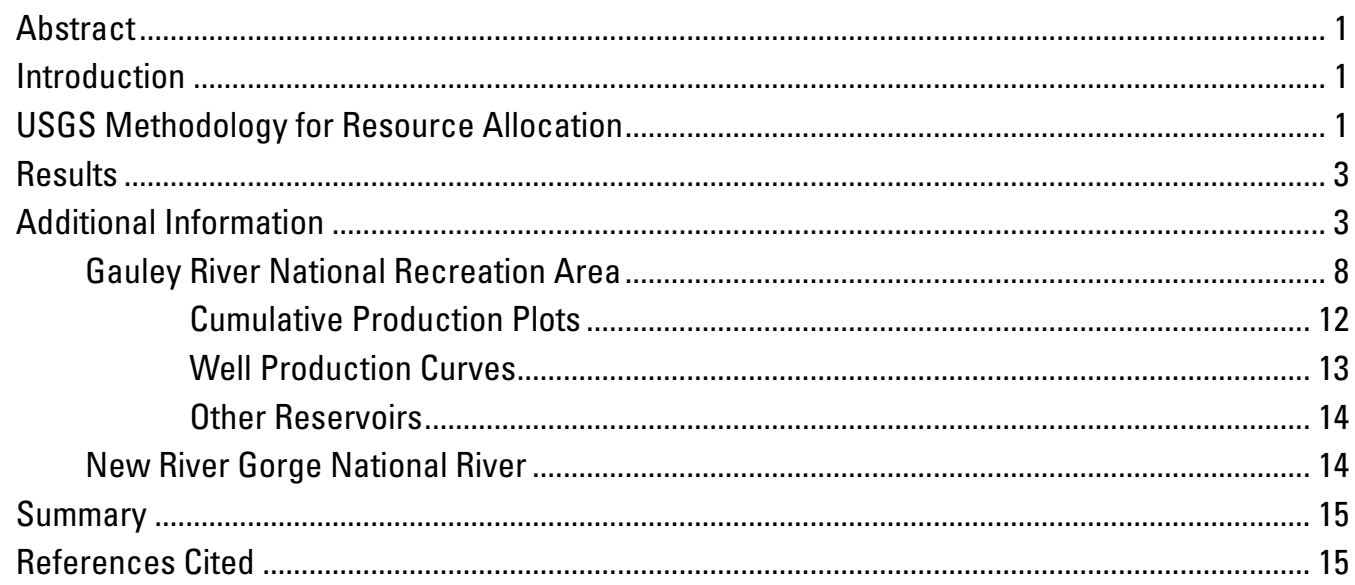

\section{Figures}

1. Map showing the locations of Gauley River National Recreation Area and New River Gorge National River in southeastern West Virginia.

2. Stratigraphic column for the Mississippian-age rocks in the area of southeastern West Virginia from Barlow (1996) and Matchen and Vargo (1996).................................................... 4

3. Stratigraphic column for the Middle and Late Devonian-age rocks in the area of southeastern West Virginia from Milici (1996) 5

4. Cells in the vicinity of Gauley River NRA and New River Gorge NR are almost entirely gas cells that are producing at present or have produced gas in the past. Few cells are classified as oil cells, although oil and condensate is produced along with gas from some cells.

5. Cells in the vicinity of Gauley River NRA and New River Gorge NR produce mainly from the Mauch Chunk Group (Ravencliff Member of the Hinton Formation, Maxon Sandstone (informal)), Big Injun Sandstone (informal), Weir Sandstone (informal), and the "Big Lime" of the Greenbrier Group

6. Map of Gauley River NRA showing the present-day extent of the Gauley Mountain Field and the Twenty Mile Creek East Field. About 58 percent of Gauley River NRA is within these fields. New field discoveries are possible in the other 42 percent of the NRA east of these fields.

7. Map of New River Gorge NR showing that the entire area of the NR is outside of existing fields, and all of the area has potential for new field discoveries. Note that several dry cells occur in the vicinity of New River Gorge NR. 
8. Gas field size versus discovery year for the Mississippian Sandstones Assessment Unit.

Gas field size in this study represents cumulative production only.

9. Gas field size versus discovery year for the Greenbrier Limestones Assessment Unit. Gas field size in this study represents cumulative production only.

10. Plot of Estimated Ultimate Recovery (EUR) of wells in the Mississippian Sandstones Assessment Unit. The data for this plot are mainly from wells in Kentucky, but the data are provided as a possible analog to well production in West Virginia. Data from the Kentucky Geological Survey (2003)

11. Plot of Estimated Ultimate Recovery (EUR) of wells in the Greenbrier Limestones Assessment Unit. The data for this plot are mainly from wells in Kentucky, but the data are provided as a possible, but unlikely, guide to well production in West Virginia. Data from the Kentucky Geological Survey (2003)

\section{Tables}

Table 1. USGS codes and names for ten assessment units (AU) that encompass the area of Gauley River NRA and New River Gorge NR.............................................................. 2

Table 2. Results of the resource allocation for Gauley River NRA and New River Gorge NR ........ 3

Table 3. Reservoir and production parameters for the Mississippian Sandstones Assessment Unit 10

Table 4. Reservoir and production parameters for the Greenbrier Limestone Assessment Unit 10 


\title{
An Allocation of Undiscovered Oil and Gas Resources to Gauley River National Recreation Area and New River Gorge National River, West Virginia
}

\author{
By Christopher J. Schenk, Timothy R. Klett, Ronald R. Charpentier, Troy A. Cook, Robert A. Crovelli, Richard \\ M. Pollastro, and Robert C. Milici
}

\begin{abstract}
The U.S. Geological Survey estimated volumes of undiscovered oil and gas resources that may underlie Gauley River National Recreation Area and New River Gorge National River in West Virginia. Using the results of an assessment of undiscovered resources from ten assessment units in the Appalachian Basin Province that include these land parcels, the USGS allocated 2.9 billion cubic feet of gas, 1.6 thousand barrels of oil, and 45 thousand barrels of natural gas liquids to part of Gauley River National Recreation Area, and 39 billion cubic feet of gas, 24 thousand barrels of oil, and 644 thousand barrels of natural gas liquids to New River Gorge National River. These allocated volumes of undiscovered resources represent potential volumes in undiscovered fields.
\end{abstract}

\section{Introduction}

The Central Energy Team of the U.S. Geological Survey (USGS) was asked by the National Park Service to estimate volumes of undiscovered oil and gas resources that may underlie Gauley River National Recreation Area (NRA) and New River Gorge National River (NR) in West Virginia (Figure 1). Gauley River NRA and New River Gorge NR are within the USGS Appalachian Basin Province. The undiscovered oil and gas resources of the Appalachian Basin Province were most recently assessed by the USGS in 2003 (Milici and others, 2003). The quantitative assessment of the Appalachian Basin Province formed the basis for this estimation of resources that may underlie part of Gauley River NRA and New River Gorge NR.The USGS defined twenty-six geologic assessment units within the Appalachian Basin Province, and assessed twenty-two of these assessment units for undiscovered oil and gas resources (Milici and others, 2003). Of these twentytwo assessment units, ten assessment units encompass the areas of Gauley River NRA and New River Gorge NR (Table 1). Rather than assess the areas of Gauley River and New River Gorge directly, we allocated undiscovered oil and gas resources from the ten assessment units to these land parcels.
This report summarizes the methodology for the allocation process, and provides data for additional analyses that one may want to perform regarding estimates of undiscovered resources that may underlie these land parcels.

\section{USGS Methodology for Resource Allocation}

For the ten assessment units that encompass the area of Gauley River NRA and New River Gorge NR, we made the assumption that the undiscovered resources from each of the ten assessment units were evenly distributed across each assessment unit. This assumption made the resource allocation process possible, but the distribution of resources may be more heterogeneous in each assessment unit than is indicated by this assumption. We allocated undiscovered resource to either Gauley River NRA or New River Gorge NR in the same percentage the land parcel represented in each assessment unit. For example, if New River Gorge NR represented one percent of the land area of a given assessment unit, we allocated one percent of the mean undiscovered resource to New River Gorge NR from the USGS assessment unit. This procedure was followed for each of the ten assessment units. We aggregated the allocated resources from the ten assessment units into a total volume of undiscovered resource under the assumption of perfect positive correlation of the fractiles of the distribution of assessment results.

The volumes of resource allocated to Gauley River NRA and New River Gorge NR are only for potential resources in undiscovered fields. Only the eastern part of Gauley River NRA may have potential for undiscovered fields, as Gauley Mountain Field and Twenty Mile Creek East Field cover the western part of the land parcel. For New River Gorge NR, nearly all of the area is outside of existing fields and has the potential for undiscovered fields. 


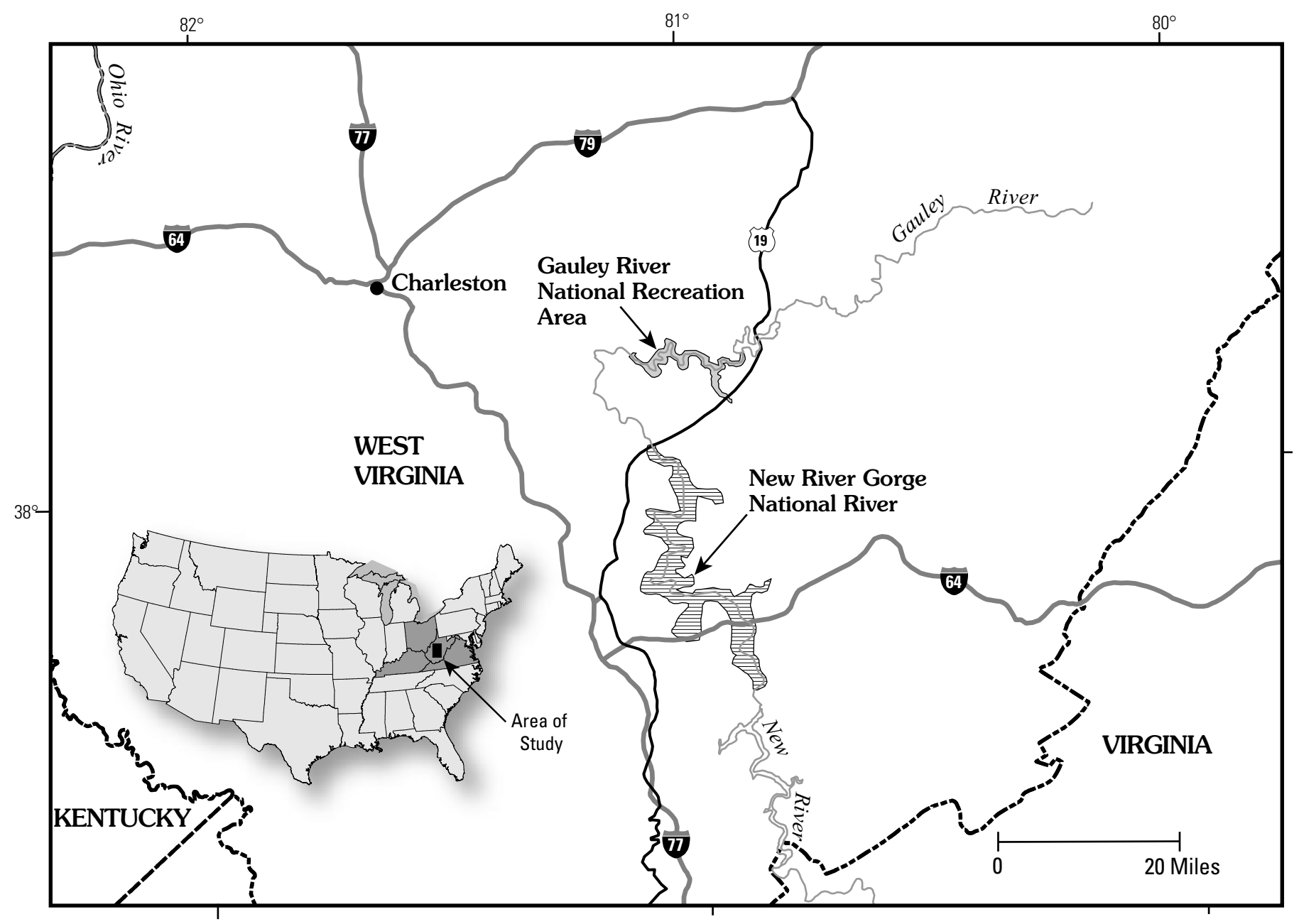

Figure 1. Map showing the locations of Gauley River National Recreation Area and New River Gorge National River in southeastern West Virginia.

\begin{tabular}{|c|l|r|}
\hline USGS AU Code & USGS AU Name & \multicolumn{1}{|c|}{ Acreage } \\
\hline 50670302 & Knox Unconformity & $72,221,653.56$ \\
50670303 & Black River-Trenton Hydrothermal & $72,097,479.75$ \\
50670364 & Tuscarora Basin Center & $27,196,113.72$ \\
50670401 & Oriskany Sandstone Structural & $8,637,505.19$ \\
50670402 & Oriskany Sandstone Stratigraphic & $22,672,865.24$ \\
50670403 & Greenbrier Limestone & $22,702,637.00$ \\
50670404 & Mississippian Sandstones & $18,736,177.69$ \\
50670463 & Devonian Siltstone and Shale & $14,664,748.41$ \\
50670464 & Marcellus Shale & $61,342,227.20$ \\
50670465 & Catskill Sandstones and Siltstones & $34,210,466.96$ \\
& & \\
& Gauley River NRA & $4,397.08$ \\
& New River Gorge NR & $64,572.28$ \\
\hline
\end{tabular}

Table 1. USGS codes and names for ten assessment units (AU) that encompass the area of Gauley River NRA and New River Gorge NR. 


\section{Results}

The allocation procedure provided an estimate of the total volume of undiscovered oil and gas resource that may underlie the eastern part of Gauley River NRA and New River Gorge NR (Table 2). The procedure outlined above resulted in 2.9 billion cubic feet of gas (BCFG), 1.6 thousand barrels of oil (MBO), and 45 thousand barrels of natural gas liquids (MBNGL) being allocated to Gauley River NRA, and 39 BCFG, $24 \mathrm{MBO}$, and $644 \mathrm{MBNGL}$ being allocated to New River Gorge NR.

The allocations show that natural gas and associated natural gas liquids are the resources that may be expected from Gauley River NRA and New River NR. Oil is estimated to be a minor resource in these areas.

The allocated volumes of undiscovered resources are total volumes that may underlie these land parcels. Data provided in the following section can be used to make a rough estimation of the sizes and numbers of undiscovered fields that these volumes may represent.

For the area of Gauley River NRA that is within the Gauley Mountain Field and Twenty Mile Creek East Field, there is the potential for additions to reserves through reserve growth. We did not attempt to estimate the volume of potential reserve growth within these fields for this study. However, data provided in the following section may allow one to make a rough estimation of some aspects of potential reserve growth within these fields.

\section{Additional Information}

In this section we provide additional data, explanations, and guidance if one wants to 1) estimate mean sizes and numbers of potential undiscovered gas fields that these total allocated volumes may represent, and 2) to allow a rough estimation of the potential for infill drilling in that portion of Gauley River NRA that lies within Gauley Mountain and Twenty Mile Creek East fields.

Most of the production in the area of Gauley River NRA and New River Gorge NR is from reservoirs in the Mississippian Sandstones Assessment Unit and the Greenbrier Limestone Assessment Unit, although significant future potential may exist in reservoirs from several other assessment units such as the Devonian Siltstone and Shale Assessment Unit, Marcellus Shale Assessment Unit, and the Catskills Sandstones and Siltstones Assessment Unit (Table 1). Although there is no current production from these three assessment units in the study area, the potential of these units should be considered in any development scenario. The stratigraphic terminology for the Mississippian-age and Middle and Late Devonian-age stratigraphic sections in West Virginia is shown in Figures 2 and 3.

Cell data indicate that nearly all cells in the vicinity of Gauley River NRA and New River Gorge NR are gas cells, either gas cells that are producing today or have produced in the past (IHS Energy Group, 2002). Few oil cells are present in the area (Figure 4). However, oil and natural gas liquids may be produced along with the gas from some cells. The cell data also indicate that, in the past, the major reservoirs in the vicinity of Gauley River NRA and New River Gorge NR are in the Mississippian Sandstones Assessment Unit, including the Mauch Chunk Group (Ravencliff Member of the Hinton Formation, Maxon Sandstone (informal), Princeton Sandstone), Big Injun Sandstone (informal), Weir Sandstone (informal); and in the Greenbrier Limestone Assessment Unit, mainly the "Big Lime" reservoir (Figure 5). However, significant future potential may exist mainly from Devonian-age reservoirs. As

\begin{tabular}{|l|c|c|c|c|c|c|}
\hline \multirow{2}{*}{ Assessment Unit } & \multicolumn{3}{|c|}{ Gauley River NRA } & \multicolumn{3}{c|}{ New River Gorge NR } \\
\cline { 2 - 7 } & $\begin{array}{c}\text { Mean Oil } \\
\text { MBO }\end{array}$ & $\begin{array}{c}\text { Mean Total Gas } \\
\text { BCF }\end{array}$ & $\begin{array}{c}\text { Mean Liquids } \\
\text { MBNGL }\end{array}$ & $\begin{array}{c}\text { Mean Oil } \\
\text { MBO }\end{array}$ & $\begin{array}{c}\text { Mean Total Gas } \\
\text { BCF }\end{array}$ & $\begin{array}{c}\text { Mean Liquids } \\
\text { MBNGL }\end{array}$ \\
\hline Knox Unconformity & 0 & 0.03 & 0.25 & 0 & 0.37 & 3.7 \\
Black River-Trenton & 0 & 0.11 & 1.10 & 0 & 1.63 & 16.3 \\
Hydrothermal Dolomite & 0 & 0.42 & 1.68 & 0 & 6.21 & 24.8 \\
Tuscarora Basin Center & 0 & 0.19 & 1.16 & 0 & 0 & 0 \\
Oriskany Sandstone-Structural & 0 & 0 & 0 & 0 & 0.18 & 1.48 \\
Oriskany Sandstone-Stratigraphic & 0.47 & 0.03 & 0.24 & 6.95 & 0.37 & 3.47 \\
Greenbrier Limestone & 1.17 & 0.03 & 0.24 & 17.48 & 0.42 & 4.60 \\
Mississippian Sandstone & 0 & 0.39 & 9.31 & 0 & 5.69 & 136.6 \\
Devonian Siltstone and Shale & 0 & 0.14 & 0.81 & 0 & 2.02 & 12.1 \\
Mariellus Shale & 0 & 1.53 & 30.53 & 0 & 22.07 & 441.4 \\
Catskill Sandstones and Siltstones & 1.6 & 2.9 & 45.0 & 24.0 & 39.0 & 644.0 \\
\hline \multicolumn{1}{|c|}{ Totals } & & & & 0 & 2 \\
\hline
\end{tabular}

Table 2. Results of the resource allocation for Gauley River NRA and New River Gorge NR. 


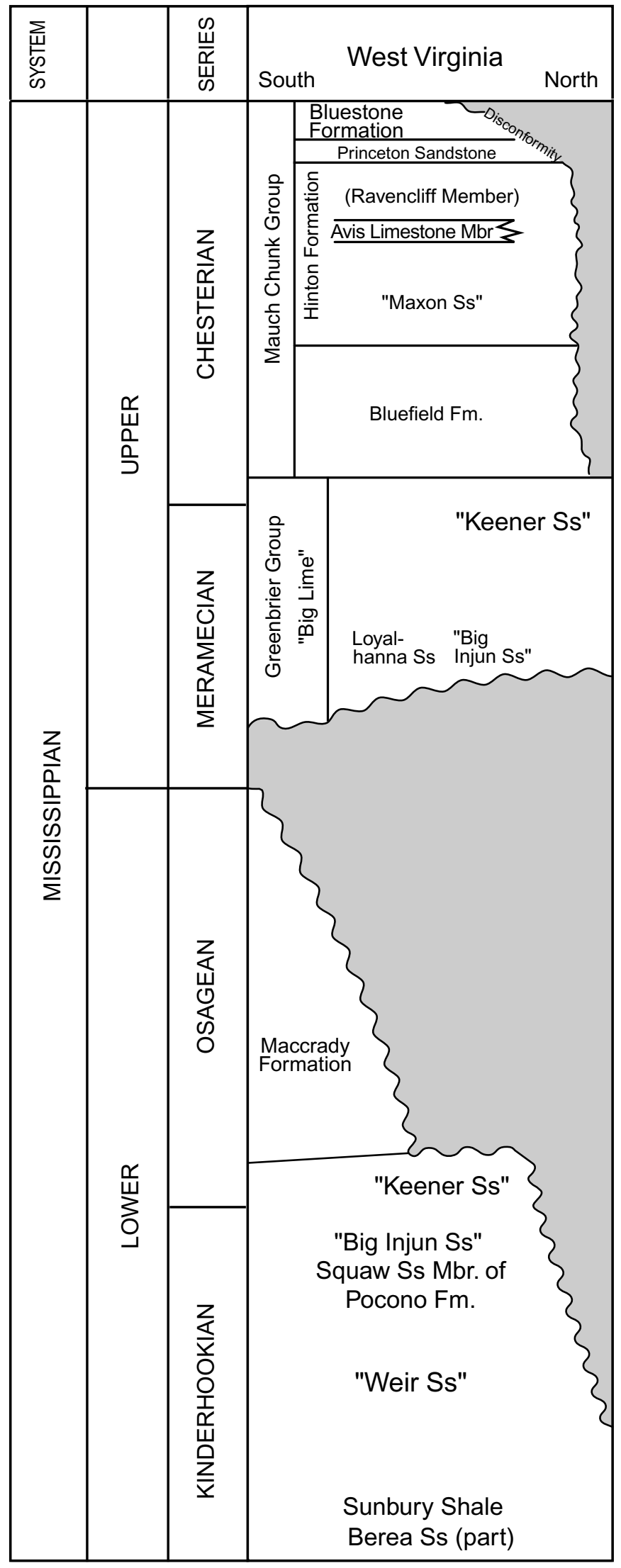

Figure 2. Stratigraphic column for the Mississippian-age rocks in the area of southeastern West Virginia from Barlow (1996) and Matchen and Vargo (1996). 


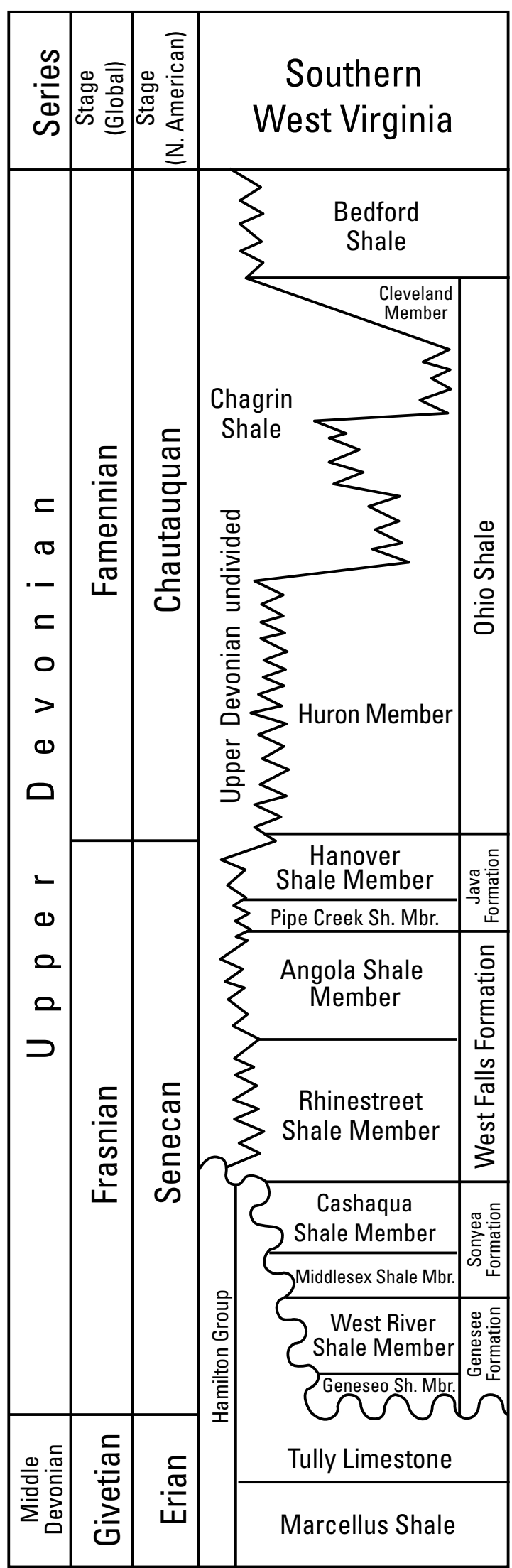

Figure 3. Stratigraphic column for the Middle and Late Devonian-age rocks in the area of southeastern West Virginia from Milici (1996). 


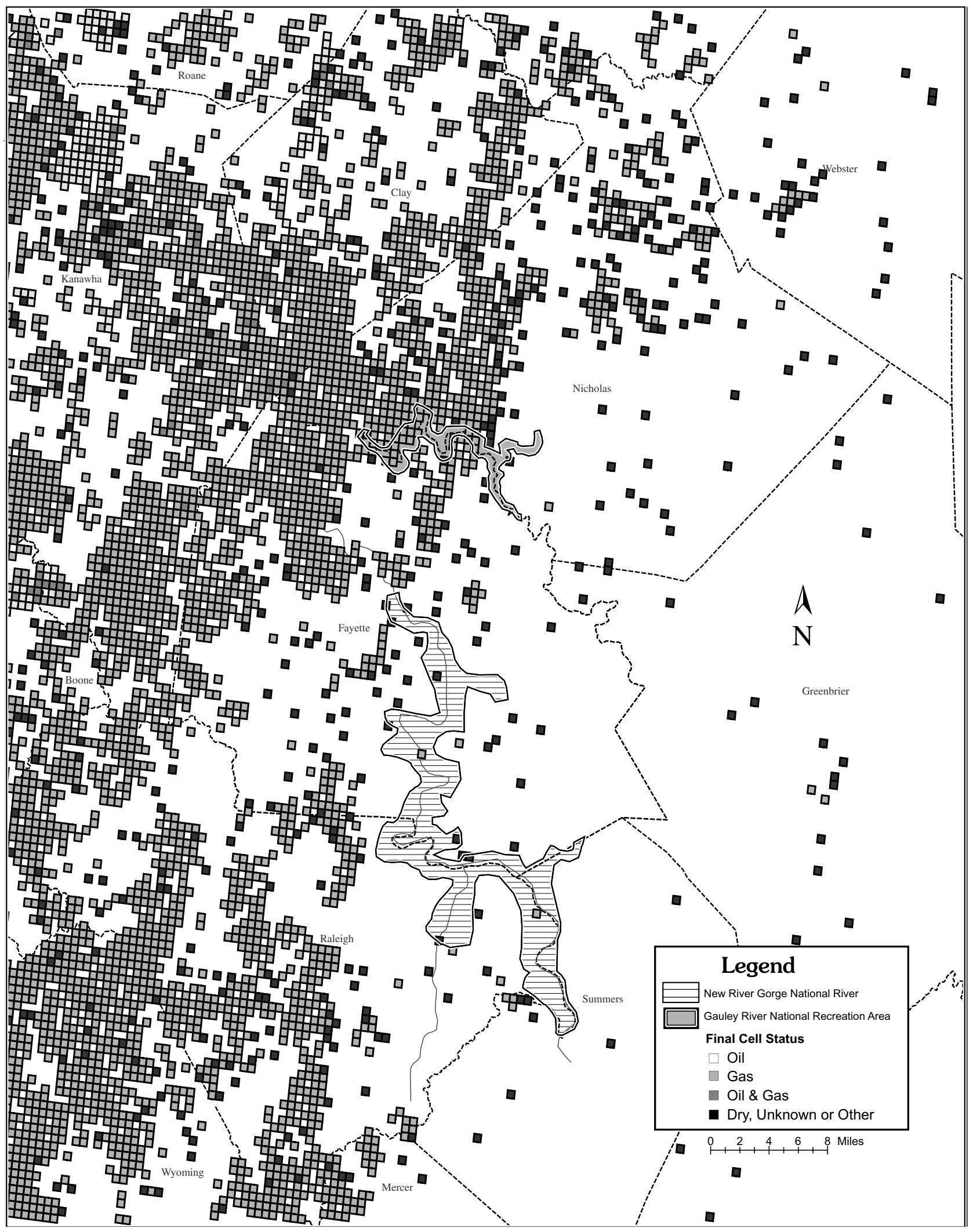

Figure 4. Cells in the vicinity of Gauley River NRA and New River Gorge NR are almost entirely gas cells that are producing at present or have produced gas in the past. Few cells are classified as oil cells, although oil and condensate is produced along with gas from some cells. 


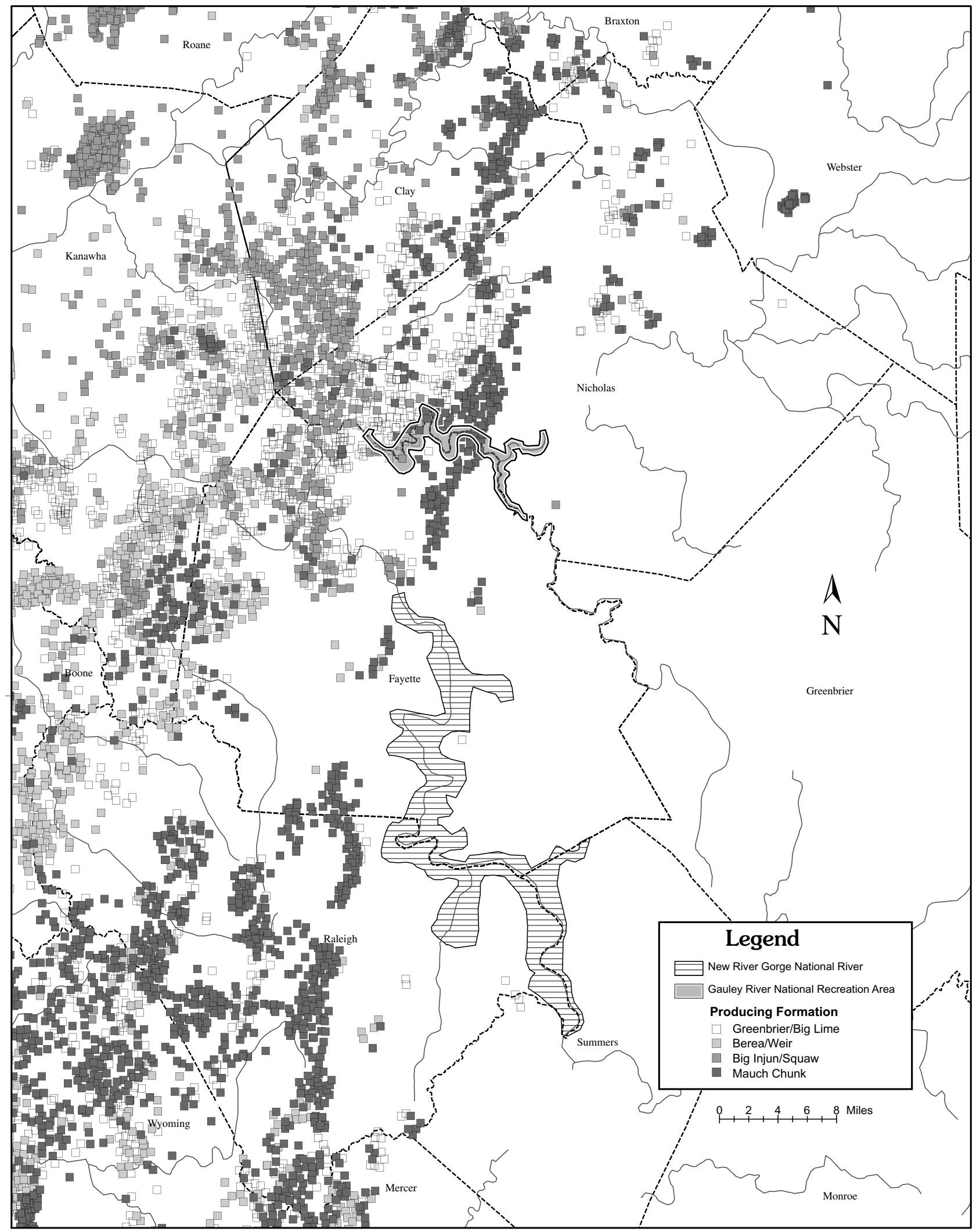

Figure 5. Cells in the vicinity of Gauley River NRA and New River Gorge NR produce mainly from the Mauch Chunk Group (Ravencliff Member of the Hinton Formation, Maxon Sandstone (informal)), Big Injun Sandstone (informal), Weir Sandstone (informal), and the "Big Lime" of the Greenbrier Group. 
part of this study, we included the potential for reservoirs in the eight other assessment units as they were mapped geologically during the USGS assessment (Table 1); these assessment units may have significant potential for undiscovered oil and gas resources in this area (Table 2). For example, seventy five percent of the undiscovered resource in the New River Gorge NR may be in Devonian reservoirs within the Devonian Siltstone and Shale AU, Marcellus Shale AU, and the Catskill Sandstones and siltstones AU. Wells targeted for reservoirs in the Mississippian Sandstones AU and Greenbrier Limestone AU would simply be drilled deeper to test the potential of any Devonian-age reservoirs.

\section{Gauley River National Recreation Area}

Our mapping of oil and gas cells and fields in the area of Gauley River NRA indicates that the western portion of Gauley River NRA is situated within two gas fields; Gauley Mountain Field and Twenty Mile Creek East Field (Figure 6). The existing boundaries of these fields are not known with certainty due to incomplete data (IHS Energy Group, 2002). In our estimation, approximately 58 percent of Gauley River NRA lies within these fields, and approximately 42 percent is outside of these fields. This distinction is important because volumes of undiscovered resource allocated by the USGS are for undiscovered fields only; areas within existing fields are not included in the assessment for undiscovered fields, but rather for reserve growth potential. Only the eastern part of Gauley River NRA is considered to have potential for undiscovered fields (Figure 6).

For the area of Gauley River NRA within the Gauley Mountain and Twenty Mile Creek East fields, the potential for additions to reserves may be from reserve growth. Reserve growth includes the finding and development of new, possibly deeper, reservoirs; infill drilling within producing reservoirs; and extension of the field boundaries through additional delineation drilling. Within these two fields, there is potential for reserve growth through the addition of significant new reservoirs, including additional Mississippian reservoirs, fractured Middle and Late Devonian shale reservoirs, and others (Table 1).

There is also potential for infill drilling in these two fields. Gauley Mountain Field has been drilled at a spacing of approximately 160 acres within Mississippian reservoirs (IHS Energy Group, 2002). There are two approaches to the analysis of infill drilling. The first is to determine if more wells could potentially be drilled so that the Gauley Mountain Field area that is coincident with Gauley River NRA is drilled entirely at a 160-acre spacing (Figure 6). Based on available well data (IHS Energy Group, 2002), which we believe accounts for most wells drilled within Gauley River NRA, more wells could be drilled within Gauley Mountain Field at a 160-acre spacing. However, the area of Gauley Mountain Field has significant topographic relief, which makes the siting of wells in a grid-like, 160-acre pattern difficult. In the future, directional drilling and perhaps horizontal drilling may be used to recover additional gas resources from this field.

The second approach is to determine if the wells in the field could be drilled at a smaller spacing without interfering with other wells. The USGS approach to this problem is to utilize reservoir properties and production data in a simple reservoir model to determine if closer infill spacing is possible without well interference during production (Tables 3 , 4). For Mississippian-age sandstone and limestone reservoirs, given the reservoir parameters in a recent compilation (Barlow, 1996; Matchen and Vargo, 1996; Smosna, 1996; Vargo and Matchen, 1996), we concluded that the 160-acre spacing was appropriate for draining these reservoirs. If the reservoir parameters locally are better than the values shown in Tables 3 and 4, a well could drain more than 160 acres. However, if other reservoirs, such as deeper, fractured Devonian shales or low-permeability Devonian sandstones, are produced in the future, a closer spacing may be required to drain these types of reservoirs that may have poor reservoir properties.

For the area of Twenty Mile Creek East Field that lies within Gauley River NRA, the available data shows that spacing of cells is variable, with spacing ranging between 80 and 160 acres (Figure 7). As with Gauley Mountain Field, topography in this area may interfere with a rigorous 160 -acre spacing. The reservoirs in this field are mainly sandstones in the Mississippian-age Mauch Chunk Group, including the Ravencliff Member of the Hinton Formation and Maxon Sandstone (informal). Using values of reservoir properties of these reservoirs from the Appalachian Gas Atlas (Barlow, 1996; Matchen and Vargo, 1996; Smosna, 1996; Vargo and Matchen, 1996), we determined that the spacing of 160 acres is appropriate for drainage of these reservoirs. However, some of the sandstone reservoirs with low permeabilities may be adequately drained without interference at a spacing less than 160 acres.

For the eastern part of Gauley River NRA that has the potential for undiscovered fields, we estimated an allocated volume of 2.9 BCFG, 1.6 MBO, and 45 MBNGL. The 45 MBNGL represents liquids, both natural gas liquids and minor oil, which may be recovered during the production of natural gas. The estimate of liquids is based on the ratio of natural gas to liquids that was calculated from each assessment unit assessed by the USGS. The volume of liquids was allocated to Gauley River NRA using this ratio. The ratio was calculated for the entirety of each assessment unit; the ratio may not be strictly applicable to the much smaller areas of Gauley River NRA and New River Gorge NR.

The allocations provide a total volume of undiscovered resource that may underlie these land parcels. Estimates can be made of mean sizes and numbers of undiscovered gas fields that these volumes of undiscovered resource might represent. To do this requires some knowledge of gas field sizes in the assessment units associated with Gauley River NRA and New River Gorge NR and how the sizes of discovered gas fields have changed through time. Unfortunately, field size information is not available for oil and gas fields in the Appalachian Basin Province (Nehring and Associates, 2002).

The ultimate size of an oil or gas field, as defined by the 


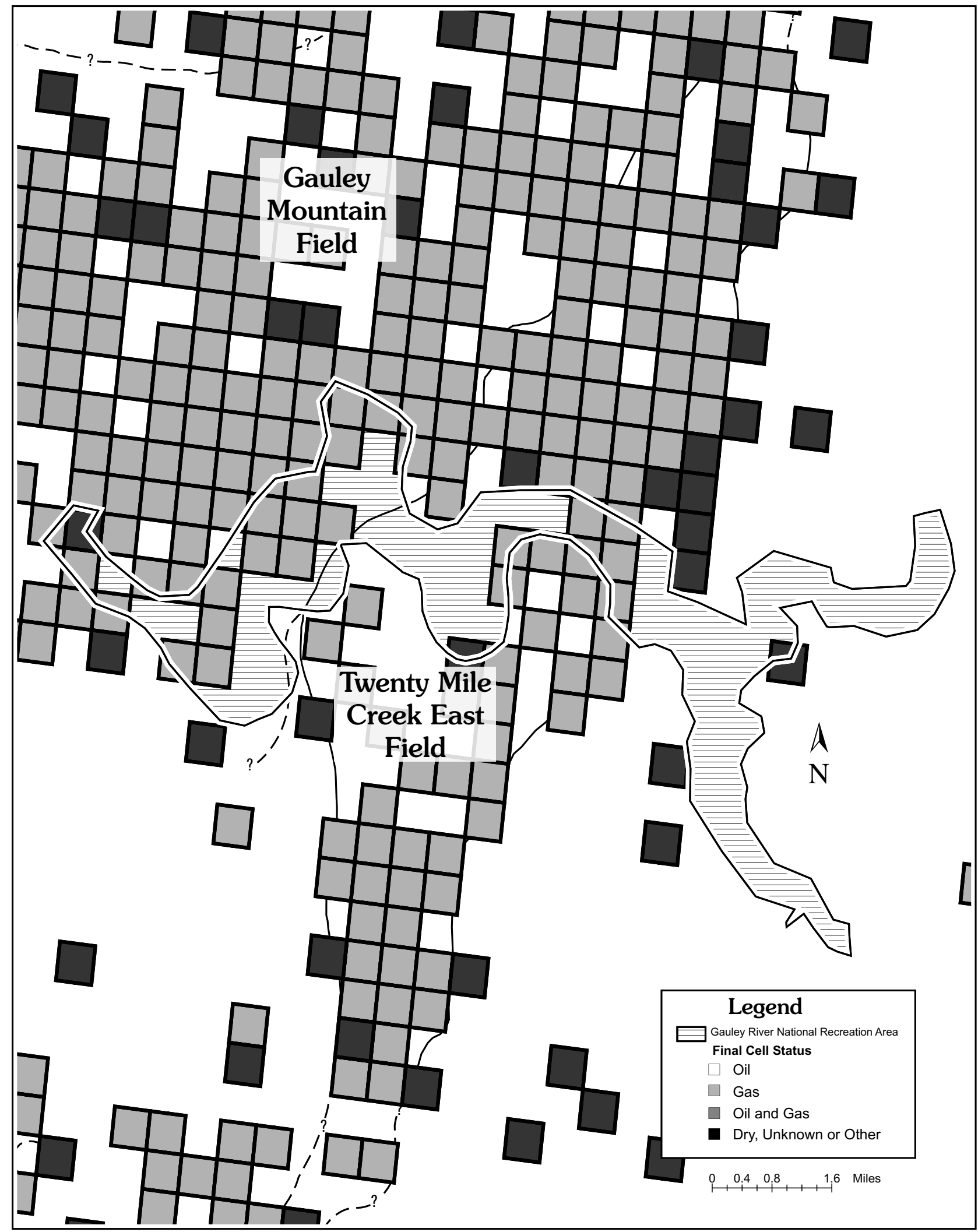

Figure 6. Map of Gauley River NRA showing the present-day extent of the Gauley Mountain Field and the Twenty Mile Creek East Field. About 58 percent of Gauley River NRA is within these fields. New field discoveries are possible in the other 42 percent of the NRA east of these fields. 


\begin{tabular}{|r|c|c|c|c|}
\hline Field Example & $\begin{array}{c}\text { Maxon Ss } \\
\text { Twenty Mile Creek East }\end{array}$ & $\begin{array}{c}\text { Ravencliff Ss } \\
\text { Rhodell }\end{array}$ & $\begin{array}{c}\text { Big Injun Ss } \\
\text { Gauley Mountain }\end{array}$ & $\begin{array}{c}\text { Weir SS } \\
\text { Ashland - Clark Gap - Ekman }\end{array}$ \\
\hline Net Pay (Ft) & 26 & 25 & 33 & 26 \\
\hline Porosity Range (\%) & $6-12$ & $6-11$ & $4-23$ & $6-15$ \\
\hline Porosity Avg. (\%) & -- & -- & 10 & 37 \\
\hline Water Saturation (\%) & -- & -- & 41 & 63 \\
\hline Gas Saturation (\%) & -- & -- & 59 & $<1$ \\
\hline Permeability (mD) & -- & -- & -- & 148 \\
\hline Avg. Cumulative & 80 & 80 & 120 & 11 \\
\hline
\end{tabular}

Table 3. Reservoir and production parameters for the Mississippian Sandstones Assessment Unit. Source: Barlow (1996), Vargo and Matchen (1996), Matchen and Vargo (1966)

\begin{tabular}{|r|c|}
\hline Field Example/Reservoir & Rhodell/ "Big Lime" \\
\hline Net Pay (Ft) & 40 \\
\hline Porosity Range (\%) & $6-15$ \\
\hline Porosity Avg. \% & 10 \\
\hline Water Saturation (\%) & 35 \\
\hline Gas Saturation (\%) & 65 \\
\hline Permeability (mD) & $<1$ \\
\hline Avg. Cumulative & 290 \\
\hline Production / Well (MMCF) & \\
\hline
\end{tabular}

Table 4. Reservoir and production parameters for the Greenbrier Limestone Assessment Unit. Source: Smosna (1996) 


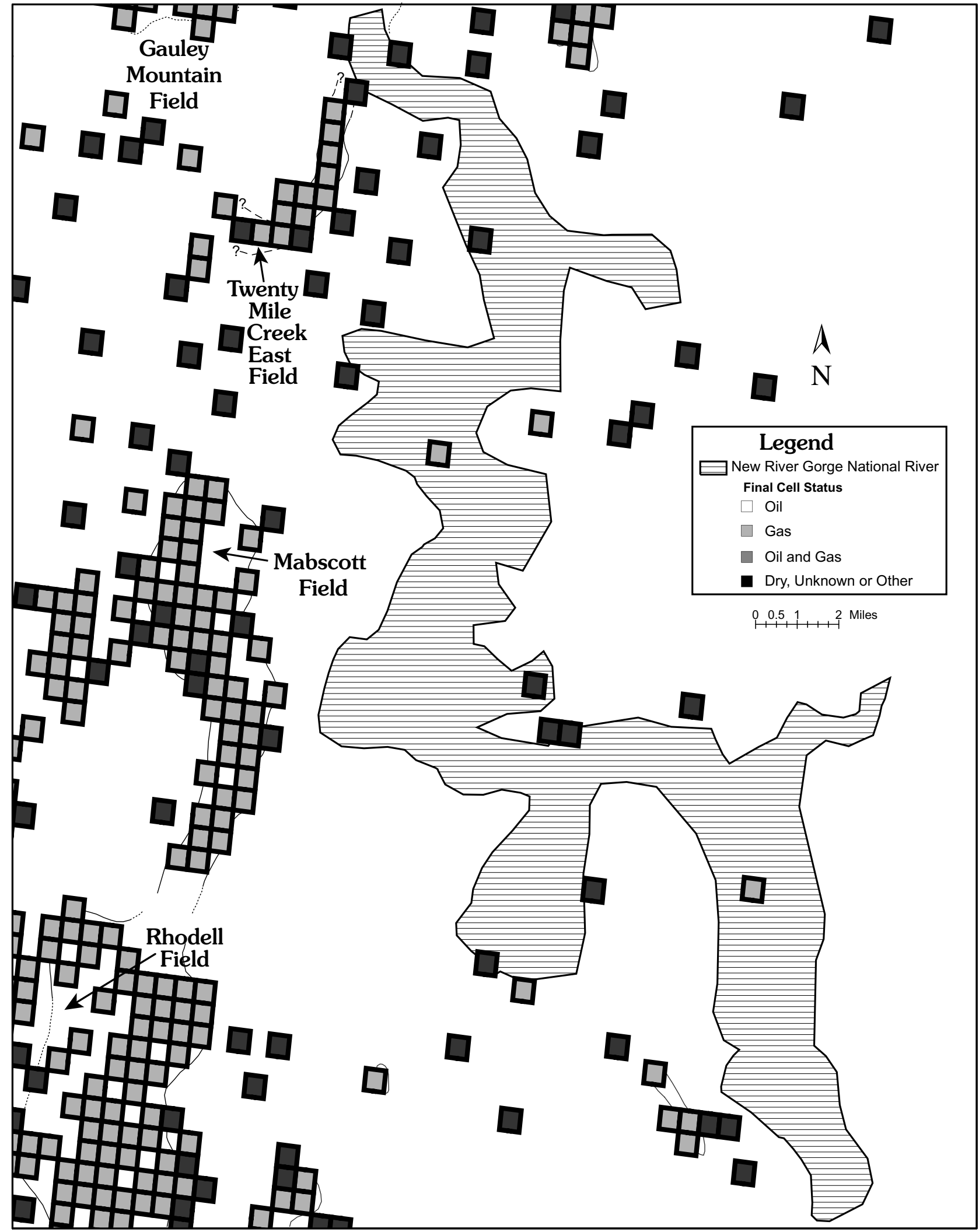

Figure 7. Map of New River Gorge NR showing that the entire area of the NR is outside of existing fields, and all of the area has potential for new field discoveries. Note that several dry cells occur in the vicinity of New River Gorge NR. 


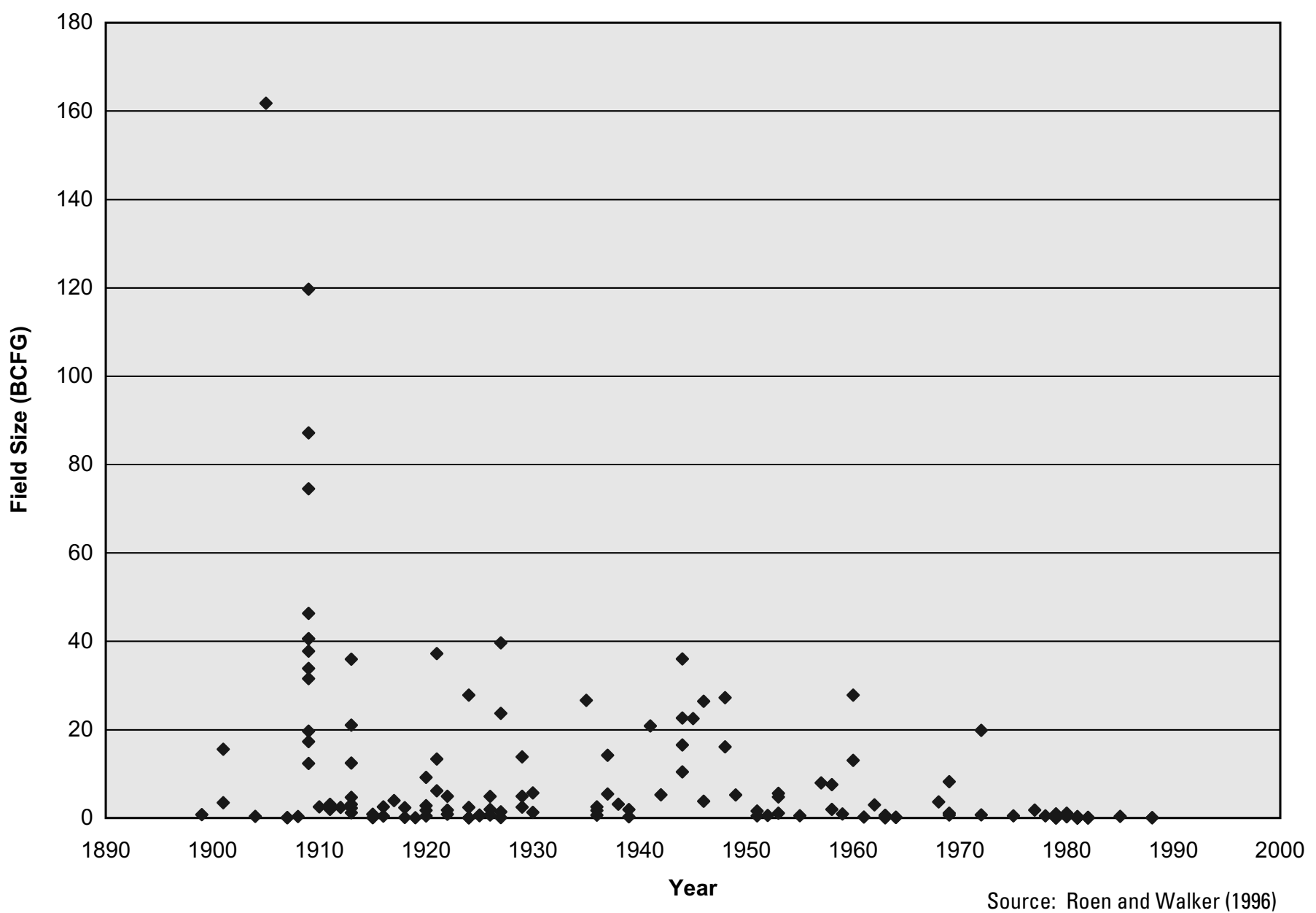

Figure 8. Gas field size versus discovery year for the Mississippian Sandstones Assessment Unit. Gas field size in this study represents cumulative production only.

USGS, is the summation of three quantities; cumulative oil and gas production, an estimation of oil and gas reserves, and an estimation of reserve growth. Together, these quantities (or the field size) provide a volume that is the total recoverable volume of hydrocarbons that can be expected during the producing life of a field. For most of the Appalachian Basin Province, the best data we have is an incomplete database for cumulative production for some, not all, fields. Most of the data on cumulative production comes from the Appalachian Gas Atlas (Roen and Walker, 1996). We do not have reserve estimates or reserve growth estimates for gas fields within the Appalachian Basin Province.

An analysis of production from oil and gas wells in the vicinity of Gauley River NRA and New River Gorge NR indicates that reservoirs in the Mississippian Sandstones Assessment Unit and the Greenbrier Limestone Assessment Unit are the most productive to date in the study area, although significant potential may exist in deeper Devonian-age reservoirs. Some reservoirs within the Mississippian Sandstones Assessment Unit crop out along the walls of the New River Gorge $\mathrm{NR}$, and thus may not have similar potential for undiscovered gas resources over the total area of New River Gorge NR.

The Mississippian Sandstones Assessment Unit includes known reservoirs of the Maxon Sandstone (informal), Ravencliff Member of the Hinton Formation, Princeton Sandstone, Big Injun Sandstone (informal), and Weir sandstones (informal) (Figure 2). The Greenbrier Limestone Assessment Unit includes the Greenbrier Group, of which the oolitic "Big Lime" reservoirs are the most productive (Figure 2). Using the data on a diskette provided with the Appalachian Gas Atlas (Roen and Walker, 1996), we constructed plots of cumulative production against field discovery year to discern trends in field sizes with time in these two assessment units.

\section{Cumulative Production Plots}

The plot of gas field size, represented by cumulative production only, versus discovery year for the Mississippian Sandstones Assessment Unit is shown in Figure 8. Although we typically use "discovery year" in plots such as this, for the Appalachian Basin Province data, the "year" in reality is the first year production data was recorded for a field. This "year" may or may not be the true discovery year, and many fields in West Virginia may have produced oil and gas before data were reported to the State. In West Virginia, for example, oil and 
gas producers were not required to report production data until 1979, and so for many older fields production data does not begin until 1979 or later.

The plot for the Mississippian Sandstones Assessment Unit illustrates a rather dramatic decline in the sizes of discovered fields with time. The larger fields were discovered early in the exploration history, and since then only small fields have come on line. There have been several decades of production for some fields, and these data indicate that the fields with primary reservoirs included in the Mississippian Sandstones Assessment Unit have a mean field size of about 9 BCFG. The larger fields may simply be ones within welldefined structures, such as anticlines, with surface expressions that were relatively easy to identify; smaller fields may, for the most part, be stratigraphic fields that are small and not as easily found as structural traps.

The plot for the Greenbrier Limestone Assessment Unit overall displays the same trend toward smaller fields with time, but shows more scatter than the Mississippian Sandstones Assessment Unit (Figure 9). The primary reservoir in the Greenbrier Limestone Assessment Unit is a thick, porous oolitic limestone, and these reservoirs display a size distribution expected from stratigraphic reservoirs. The mean size for gas fields in the Greenbrier Limestone Assessment Unit is about 5 BCFG. These discovery history plots can be used as a rough guide to the estimation of sizes of undiscovered gas fields that may be present in the eastern part of Gauley River NRA and New River Gorge NR.

\section{Well Production Curves}

Well production curves are provided as a guide to possible Estimated Ultimate Recoveries (EUR) of wells that may produce from reservoirs in these land parcels. We constructed plots illustrating EUR of wells that have produced from the major reservoir units for each assessment unit. Estimates of average well production can be used as an approximate guide to determine the mean numbers of wells that may be required to recover gas from accumulations in the eastern part of Gauley River NRA and New River Gorge NR.

The EUR plot for sandstone reservoirs in the Mississippian Sandstones Assessment Unit is shown in Figure 10. The median EUR is approximately 80 million cubic feet of gas (MMCFG), and the maximum EUR from data available to us is just over $1000 \mathrm{MMCFG}$, or 1 billion cubic feet of

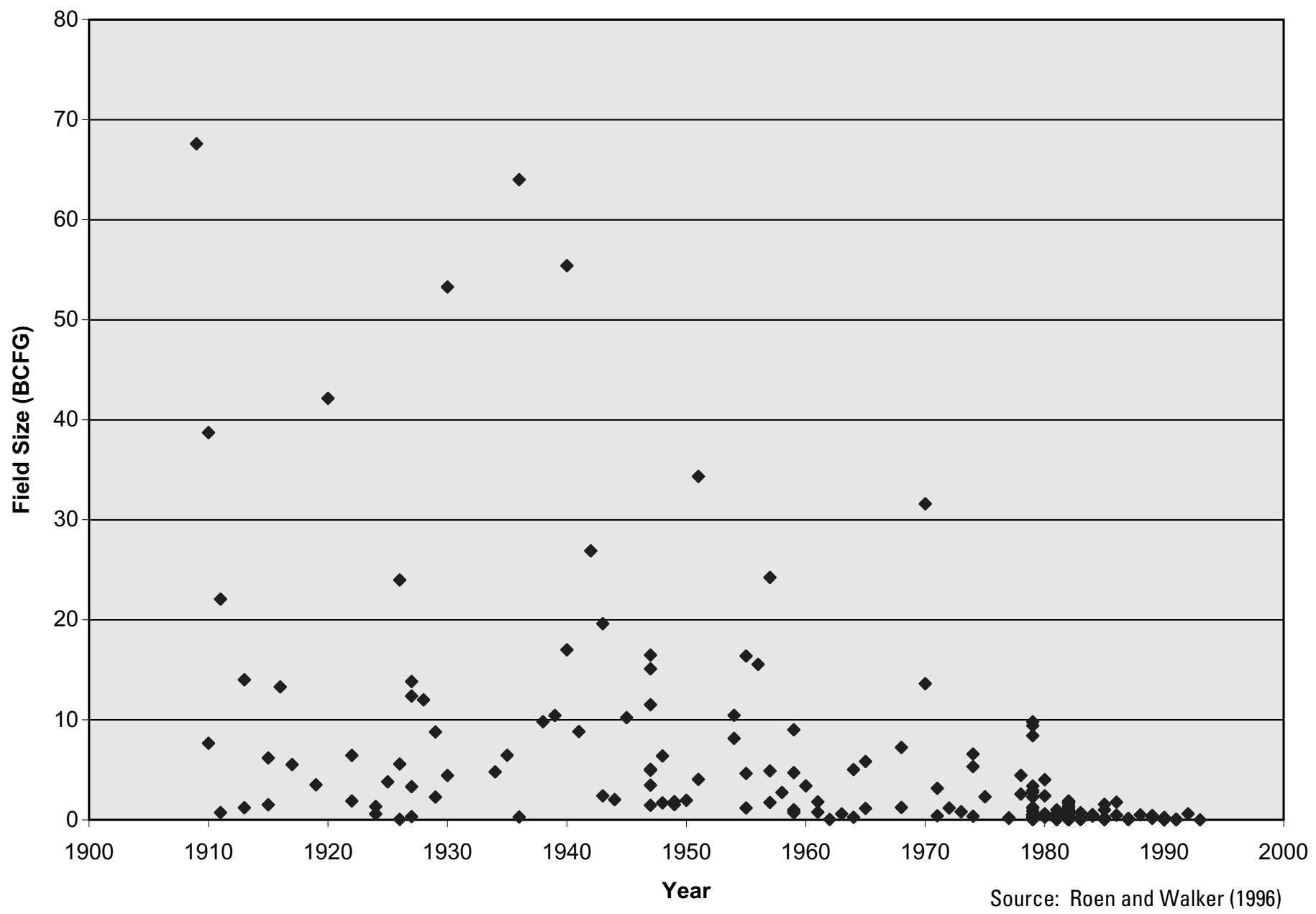

Figure 9. Gas field size versus discovery year for the Greenbrier Limestones Assessment Unit. Gas field size in this study represents cumulative production only. 


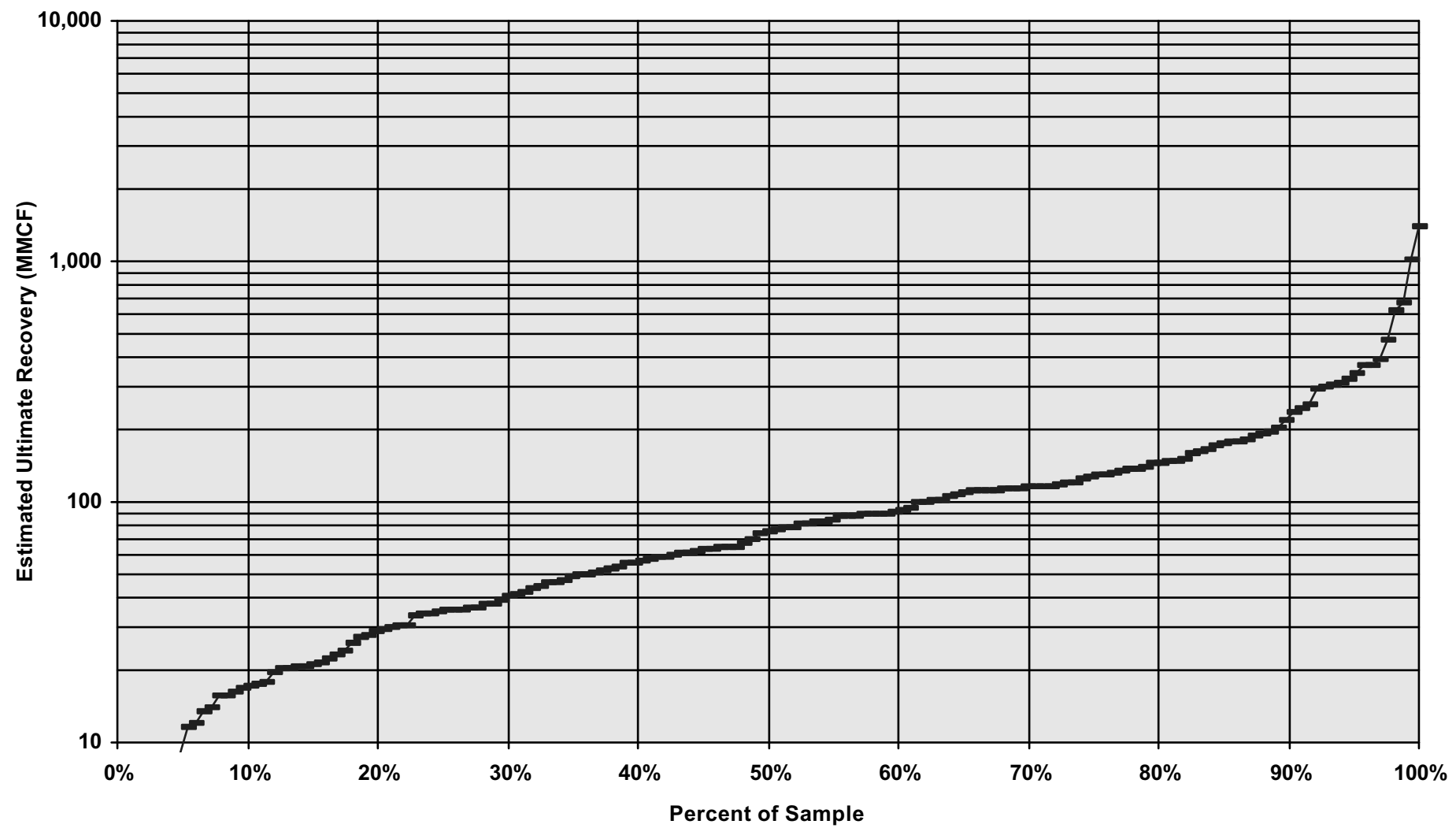

Figure 10. Plot of Estimated Ultimate Recovery (EUR) of wells in the Mississippian Sandstones Assessment Unit. The data for this plot are mainly from wells in Kentucky, but the data are provided as a possible analog to well production in West Virginia. Data from the Kentucky Geological Survey (2003).

gas (BCFG). The data used to construct this plot came from similar reservoirs in Kentucky (Kentucky Geological Survey, 2003), as the production data by well from West Virginia are not adequate to construct such a plot. These data agree with the production data cited in the Appalachian Gas Atlas (Barlow, 1996; Matchen and Vargo, 1996; Vargo and Matchen, 1996).

The EUR plot for "Big Lime" reservoirs of the Greenbrier Limestone Assessment Unit is shown in Figure 11. The median EUR is about $55 \mathrm{MMCFG}$, and the maximum EUR is just under $2000 \mathrm{MMCFG}$, or $2 \mathrm{BCFG}$. These data are also from reservoirs in Kentucky, as the West Virginia production data were not adequate for the construction of an EUR curve. In this case, the EUR curve appears to be lower than expected based on the data provided in the Appalachian Gas Atlas (Smosna, 1996). The mean well production from Greenbrier limestone reservoirs provided in the Gas Atlas is approximately $300 \mathrm{MMCFG}$. We interpret this to mean that the Kentucky data available to us were not adequate to account for gas production from "Big Lime" oolitic reservoirs in West Virginia. Given this discrepancy, using the mean well production from the Appalachian Gas Atlas (300 MMCFG) may be more appropriate in this case.

These plots illustrate production data that we have for the reservoirs currently producing in the Mississippian Sandstones Assessment Unit and the Greenbrier Limestone Assessment Unit. If additional reservoirs were added to these assessment units, these EUR data would represent a minimum case.

\section{Other Reservoirs}

In the area of Gauley River NRA and New River Gorge NR, reservoirs within the Mississippian Sandstones AU and Greenbrier Limestone AU represent the primary producing intervals, but other reservoirs may also significantly contribute to field size in the future. Fractured reservoirs in the Devonian Siltstone and Shale Assessment Unit may be a significant reservoir in the future, as may be fractured shales of the Marcellus Shale Assessment Unit and reservoirs in the Catskill Sandstones and Siltstones Assessment Unit. These deeper reservoirs may be tested and produced in the future in Gauley River NRA and New River Gorge NR.

\section{New River Gorge National River}

Unlike Gauley River NRA, nearly all the area of New River Gorge NR appears to be outside of existing gas fields, with the exception of a small area in the northwest part of the NRA that may fall within the Twenty Mile Creek East Field (Figure 7). For this study, we considered all of New River Gorge NR to be outside existing fields. We allocated about 39 BCFG, 24 MBO, and 644 MBNGL to New River Gorge NR. 


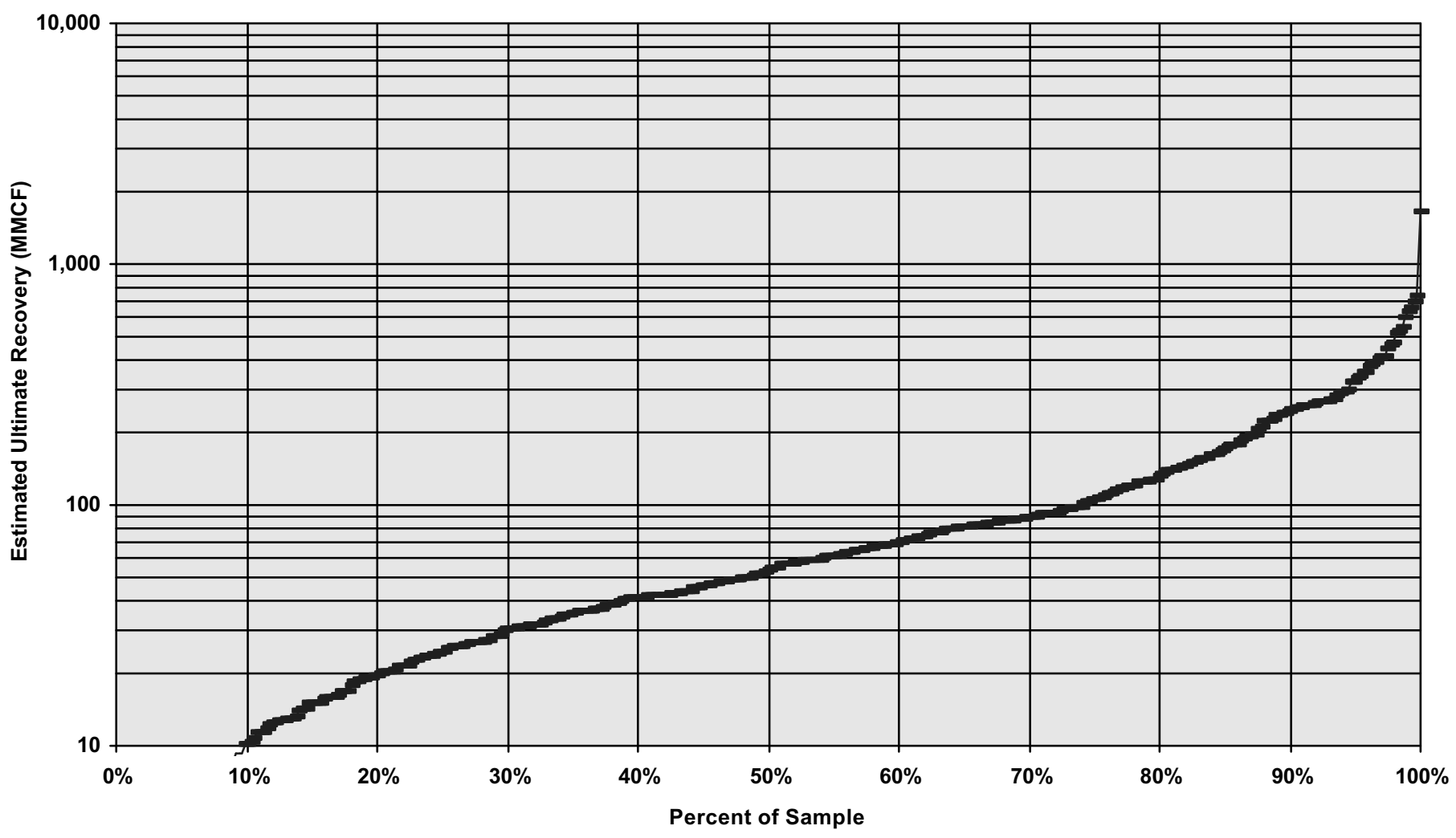

Figure 11. Plot of Estimated Ultimate Recovery (EUR) of wells in the Greenbrier Limestones Assessment Unit. The data for this plot are mainly from wells in Kentucky, but the data are provided as a possible, but unlikely, guide to well production in West Virginia. Data from the Kentucky Geological Survey (2003).

In the vicinity of New River Gorge NR there are several small fields, most of which produce from Mississippian-age limestone and sandstone reservoirs, similar to Gauley River NRA (Figure 7).

The approach to determining the possible sizes and numbers of undiscovered fields that may underlie New River Gorge NR is the same as that for Gauley River NRA, and the data plots for field sizes and well productivities may be used in this process.

\section{Summary}

Using a resource allocation procedure based on the assessment of ten assessment units from the Appalachian Basin Province, the USGS allocated 2.9 billion cubic feet of gas (BCFG), 1.6 thousand barrels of oil (MBO), and 45 thousand barrels of natural gas liquids (MBNGL) to Gauley River NRA, and 39 BCFG, $24 \mathrm{MBO}$, and $644 \mathrm{MBNGL}$ to New River Gorge NR. These allocated volumes of undiscovered resources represent only the volumes in potential undiscovered fields.

\section{References Cited}

Barlow, C.A., 1996, Play Mmc: Upper Mississippian Mauch Chunk Group and equivalent strata, in Roen, J.B., and Walker, B.J., eds., The Atlas of Major Appalachian Gas Plays: Appalachian Oil and Natural Gas Research Consortium, p. 31-36.

IHS Energy Group, 2002, PI/Dwights Plus US Production Data: database available from IHS Energy Group, 15 Inverness Way East, Englewood, Colorado, 80112.

Kentucky Geological Survey, 2003, Technical Information Library; Oil and Gas Production data, at http://dmm.ppr.ky.gov/oilandgas.htm.

Matchen D.L., and Vargo, AG., 1996, Play Mws: Lower Mississippian Weir Sandstones, in Roen, J.B., and Walker, B.J., eds., The Atlas of Major Appalachian Gas Plays: Appalachian Oil and Natural Gas Research Consortium, p. 46-50.

Milici, R.C., 1996, Play Dbg: Upper Devonian fractured black and gray shales and siltstones, in Roen, J.B., and Walker, B.J., eds., The Atlas of Major Appalachian Gas Plays: Appalachian Oil and Natural Gas Research Consortium, p. 86-92.

Milici, R.C., Ryder, R.T., Swezey, C.S., Charpentier, R.R., Cook, T.A., Crovelli, R.A., Klett, T.R., Pollastro, R.M., and Schenk, C.J. (2003), Assessment of undiscovered oil and gas resources of the Appalachian Basin Province, 2002: U.S. Geological Survey Fact Sheet FS-009-03. 
Nehring and Associates (2002) Significant oil and gas field file for the United States; data available from Nehring and Associates, Colorado Springs, Colorado, one CD-ROM.

Roen, J.B., and Walker, B.J., 1996, The Atlas of Major Appalachian Gas Plays: Appalachian Oil and Natural Gas Research Consortium, $201 p$.
Smosna, R., 1996, Play Mgn: Upper Mississippian Greenbrier/Newman Limestones, in Roen, J.B., and Walker, B.J., eds., The Atlas of Major Appalachian Gas Plays: Appalachian Oil and Natural Gas Research Consortium, p. 37-40.

Vargo, A.G., and Matchen, D.L., 1996, Play Mbi: Lower Mississippian Big Injun Sandstones, in Roen, J.B., and Walker, B.J., eds., The Atlas of Major Appalachian Gas Plays: Appalachian Oil and Natural Gas Research Consortium, p. 41-45. 